\title{
Growth performance, haematological and biochemical indices of grazed Red Sokoto bucks supplemented with dried ripe plantain peels. \\ ${ }^{2 *}$ Ukanwoko, A. I., ${ }^{2}$ Douglas, N. C. and ${ }^{1}$ Igwe, N. C. \\ ${ }^{\prime}$ Department of Animal Production and Livestock Management, College of Animal Science and Animal Production, Michael Okpara University of Agriculture, Umudike, Abia State, Nigeria.

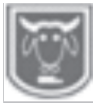 \\ ${ }^{2}$ Department of Animal Science, University of Port Harcourt, Rivers State, Nigeria. \\ Abstract \\ *Corresponding author: ndutonia@yahoo.com; +2347031126294
}

This study was conducted to evaluate the growth performance and blood profile of grazed Red Sokoto bucks supplemented with dried ripe plantain peels. Nine bucks were used for this experiment. The goats were apportioned to three treatment diets and dried ripe plantain peels incorporated at $0 \%, 5 \%$ and $10 \%$ inclusion levels for $T_{1}, T_{2}$ and $T_{3}$, respectively. The bucks were taken out for grazing in the morning (9.00am-12noon) and thereafter fed the experimental diet. The experiment lasted for eight (8) weeks. The animals were weighed at the beginning of the experiment and weekly afterwards. Feed intake was calculated as the difference between feed served and refusal. Blood samples of the bucks were collected to determine the blood profile using disposable syringes and sterile needles. Results showed that the final body weight, body weight gain and feed conversion ratio (FCR) differed significantly $(P<0.05)$. The final body weight, body weight gain and FCR were $18.02 \mathrm{~kg}$, $2.01 \mathrm{~kg}, 3.42 ; 20.75 \mathrm{~kg}, 3.89 \mathrm{~kg}, 1.26$ and $21.35 \mathrm{~kg}, 4.80 \mathrm{~kg}, 1.10$ for $T_{1}, T_{2}$ and $T_{3}$, respectively. Platelet, Alkaline phosphatase (ALP), total protein (TP), urea and creatinine values differed significantly $(P<0.05)$. The highest platelet was recorded for bucks on $T_{3}\left(212.91 \times 10^{3} / u l\right)$ while the lowest was for bucks on $T_{1}\left(202.30 \times 10^{3} / 4 l\right)$. ALP, TP, urea and creatinine values were $29.00 \mathrm{u} / \mathrm{l}, 60.00 \mathrm{~g} / \mathrm{l}, 8.00 \mathrm{~m} / \mathrm{mol}, 72.50 \mathrm{~m} / \mathrm{mol} ; 30.30 \mathrm{u} / \mathrm{l}, 52.30 \mathrm{~g} / \mathrm{l}, 10.00 \mathrm{~m} / \mathrm{mol}$, $141.00 \mathrm{~m} / \mathrm{mol}$ and $42.00 \mathrm{u} / \mathrm{l}, 53.30 \mathrm{~g} / \mathrm{l}, 9.70 \mathrm{~m} / \mathrm{mol}, 112.30 \mathrm{~m} / \mathrm{mol}$ for $T_{1}, T_{2}$ and $T_{3}$, respectively. The inclusion of supplemental dried ripe plantain peels in the diet of Red Sokoto bucks enhanced the body weight and did not have any adverse effect on their blood profile.

Keywords: Growth performance, haematological and biochemical indices of grazed Red Sokoto bucks, dried ripe plantain peels

\section{Introduction}

Goats are the most populous small ruminants in Nigeria in the tune of 72.5 million (National Agricultural Sample Survey, 2011). Within the goat breed, Red Sokoto ranks highest in population $(50 \%)$, followed by West African dwarf (45\%) and Sahel (5\%). Goats as herbivorous animals experience scarcity of forages especially during the dry season (Sodeinde et al., 2007). The search for unconventional feed ingredients (Amata, 2014) like plantain peel to replace conventional feed resources which are costly and in high demand (Ben
Salem et al., 2004) is the concern of Animal Scientists. Plantain (Musa paradisiaca) is a tropical staple food (Oladele and Khokhar, 2011) and annually over 2.11 million metric tons of it is produced in Nigeria (FAO, 2005). The major by - product of plantain is the peels which constitute $40 \%$ of the fruit (Akinsanmi et al., 2015). Ripe plantain peels contain $28.60 \%$ carbohydrate, $6.69 \%$ CP, 3.71\% CF, 1.40\% EE, 6.30\% Ash and $53.30 \%$ MC (Adamu et al., 2017). Ukanwoko et al. (2019) reported dried ripe plantain peels to have $0.08 \%$ phytate, $0.07 \%$ oxalate, $0.002 \%$ tannin and $0.23 \%$ 
saponin and all these levels of anti nutritional factors are within tolerable levels for ruminants (Onyeonagu and Njoku, 2010). This study was therefore, aimed at evaluating the performance, haematological and biochemical indices of Red Sokoto bucks fed dried ripe plantain peel diets.

\section{Materials and methods Experimental site}

The research was carried out at the University of Port Harcourt Demonstration Farm, Abuja, Rivers State, Nigeria.This farm falls within latitude $4^{0} 53^{\prime} 14^{\prime \prime} \mathrm{N}$ and longitude $6^{0} 54^{\prime} 00^{\prime} \mathrm{E}$ of the equator (Ijeomah et al., 2013). It is in the humid forest zone with rainfall from March - November which amounts to $367 \mathrm{~mm}$ of rain in 182 rain days. The temperature falls between $25^{\circ} \mathrm{C}$ and $28^{\circ} \mathrm{C}$ with high relative humidity.

\section{Experimental animals and design}

Nine Red Sokoto bucks of the age 5-7 months from the University farm were used. The nine goats were allocated to three treatment diets $\mathrm{T}_{1}, \mathrm{~T}_{2}$ and $\mathrm{T}_{3}$ in a Completely Randomized Design. Animals were housed in individual pens, grazed in the morning and served the experimental diets in the afternoon. Daily feed intake was calculated as feed refusal subtracted from feed served. Animals were weighed at the beginning of the experiment and weekly. The trial lasted 8 weeks.

\section{Experimental diets}

Ripe plantain peels were collected from 'Bolle' sellers around the University's environs, sun - dried for 4 - 5 days on a concrete floor, milled and bagged for feed formulation. The other feed ingredients (wheat offal, palm kernel cake, soybean meal, bone meal and common salt) were purchased from the market and used for feed formulation as shown in Table 1.

Experimental procedures and data collection

Animals were housed in individual pen, grazed in the morning and served the supplemental diets in the afternoon. Daily feed intake was calculated as feed refusal subtracted from feed served. Animals were weighed at the beginning of the experiment and weekly. The trial lasted 8weeks. Blood samples of the nine bucks were collected to determine the blood profile of the animals using disposable syringes and sterile needles (needle length (1-2). An average of $10 \mathrm{~mL}$ blood was collected from each animal. $5 \mathrm{~mL}$ of blood sample collected was put in a plastic tube containing EDTA (ethylene diamine tetra-acetic acid) and used to determine the haematological parameters such as Red blood cells (RBC), White blood cells (WBC), Packed cell volume (PCV) and haemoglobin $(\mathrm{Hb})$ according to Joshi et al (2002). The remaining $5 \mathrm{ml}$ blood sample collected in plastic tube without anticoagulant was used to determine the serum biochemical indices such as the Aspartate aminotransferase (AST), Alanine aminotransferase (ALT), Alkaline phosphatase (ALP), total protein, albumin, potassium, chloride, urea and creatinine using the methods described by Ogunsami et al. (2002).

\section{Statistical analysis}

The data collected were subjected to the analysis of variance (Steel and Torrie, 1980), significant means were also separated (Duncan 1955).

\section{Results and discussion}

The proximate composition of the experimental diets, dried ripe plantain peels and browsed grasses/legumes is shown in Table 2. The crude protein content of the experimental diets fell within the range of $17.60-21.20 \%$ and this range is well above the CP contents of $10.25 \%$ and $13.73 \%$ recommended for sheep and goat production by Abdu et al (2012) and Okafor et al (2012), respectively. The crude fibre of the diets fell within the range of $10.63-$ $12.79 \%$. Apart from $\mathrm{T}_{1}, \mathrm{~T}_{2}$ and $\mathrm{T}_{3}$ have $\mathrm{CF}$ 


\section{Ukanwoko, Douglas and Igwe}

contents that compare favourably with the $12 \%$ CF recommended for goat production by Rashid (2008). The CP content of $10.04 \%$ reported for dried ripe plantain peels in this study is higher than a $\mathrm{CP}$ content of $9.04 \%$ reported by Aregheore (1998) for dried ripe plantain peels. The variation might be due to the differences in location of the study (South - south zone of Nigeria). The CF content of $9.53 \%$ reported for dried ripe plantain peels in this study is higher than that $(5.63 \%)$ reported by Fanimo and Odu (1996) but lower than that $(10.85 \%)$ reported by Kalio et al. (2013) for dried ripe plantain peels. The variations in nutrient composition might be due to differences in variety, sampling and analytical procedures (Gizzi and Givens 2004). The growth performance of grazing
Red Sokoto bucks fed dried ripe plantain peel diets is presented in Table 3. There were significant $(\mathrm{P}<0.05)$ differences in the final body weight, body weight gain and feed conversion ratio of the bucks on the experimental diets. The final body weight was highest for goats that fed the dried ripe plantain peel diets. This agrees with the reports of Aregheore (1998). This is also true for the body weight gain of the bucks. Kalio et al. (2013) also reported a significant effect in the body weight gain of goats that fed on dried ripe plantain peel diets. Feed conversion ratio was best for the dried ripe plantain peel diets; 1.10 and 1.26 for $\mathrm{T}_{2}$ and $\mathrm{T}_{3}$ respectively. This disagrees with Kalio et al. (2013) who reported a poorer FCR for West African Dwarf goats fed dried ripe plantain peels diets.

Table 1: The experimental diet

\begin{tabular}{llll}
\hline \multirow{2}{*}{ Ingredients } & \multicolumn{2}{c}{ Treatments } \\
\cline { 2 - 4 } & $\mathbf{T}_{\mathbf{1}}$ & $\mathbf{T}_{\mathbf{2}}$ & $\mathbf{T}_{\mathbf{3}}$ \\
\hline Wheat offal & 65.00 & 62.00 & 57.00 \\
Dried ripe plantain peels & 0.00 & 5.00 & 10.00 \\
Palm kernel cake & 22.00 & 20.00 & 20.00 \\
Soyabean meal & 10.00 & 10.00 & 10.00 \\
Bone meal & 2.00 & 2.00 & 2.00 \\
Common salt & 1.00 & 1.00 & 1.00 \\
Total & 100 & 100 & 100 \\
\hline
\end{tabular}

Table 2: Proximate composition of the experimental diets, $\mathrm{dr}$ ied ripe plantain peels browsed grasses/legumes

\begin{tabular}{llllll}
\hline \multicolumn{5}{c}{ Treatments } \\
\hline Parameters (\%) & $\mathbf{T}_{\mathbf{1}}$ & $\mathbf{T}_{\mathbf{2}}$ & $\mathbf{T}_{\mathbf{3}}$ & $\mathbf{D R P P}$ & $\mathbf{B G} / \mathbf{L}$ \\
\hline Dry matter & 86.75 & 87.52 & 88.90 & 92.30 & 45.90 \\
Crude protein & 17.60 & 18.70 & 21.20 & 10.04 & 21.44 \\
Crude fibre & 10.63 & 12.65 & 12.79 & 9.53 & 6.70 \\
Ash & 7.54 & 9.98 & 9.43 & 11.50 & 1.30 \\
Ether extract & 3.06 & 5.63 & 7.48 & 6.00 & 3.92 \\
NFE & 51.15 & 51.24 & 51.31 & 51.06 & 51.13 \\
\hline
\end{tabular}

Where DRPP $=$ Dried ripe plantain peel, $\mathrm{BG} / \mathrm{L}=$ Browsed grasses/legume

The haematological parameters of Red Sokoto bucks fed dried ripe plantain peel diet is shown in Table 4. There were no significant differences $(\mathrm{P}>0.05)$ in the $\mathrm{PCV}$,
$\mathrm{Hb}, \mathrm{RBC}, \mathrm{WBC}$, neutrophil, lymphocytes, eosinophil, and monocytes values of the bucks though they all fell within the normal range for goats (RAR 2009). The findings of 


\section{Growth performance, haematological and biochemical indices of grazed Red Sokoto bucks}

this study are in agreement with the reports of Okoruwa et al. (2014) who observed that the inclusion of plantain peel with elephant grass $(\mathrm{P}>0.05)$ did not significantly affect packed cell volume, haemoglobin, white blood cell, red blood cell, neutrophils and lymphocyte values. There were significant differences $(\mathrm{P}<0.05)$ in the platelet value of the bucks. The highest was recorded for bucks on $\mathrm{T}_{3}\left(212.91 \times 10^{3} / \mathrm{ul}\right)$. The range of $202.30-212.91 \times 10^{3} /$ ul platelet recorded for bucks in this study fell within the normal range of $150-230 \times 10^{3} / \mathrm{ul}$ reported by RAR (2009) but lower than that $\left(324 \times 10^{3} / \mathrm{ul}\right)$ reported by Raji et al (2016). Platelets also known as thrombocytes play a major role in blood clotting.

Table 3: Growth performance of grazing Red Sokoto bucks fed dried ripe plantain peel diets

\begin{tabular}{lllll}
\hline & \multicolumn{3}{c}{ Treatments } & \\
\cline { 2 - 4 } Parameters & $\mathbf{T}_{\mathbf{1}}$ & $\mathbf{T}_{\mathbf{2}}$ & $\mathbf{T}_{\mathbf{3}}$ & SEM \\
\hline Initial body weight $(\mathrm{kg})$ & 16.03 & 16.86 & 16.55 & 0.27 \\
Final body weight $(\mathrm{kg})$ & $18.02^{\mathrm{b}}$ & $20.75^{\mathrm{a}}$ & $21.35^{\mathrm{a}}$ & 0.23 \\
Body weight gain $(\mathrm{kg})$ & $2.01^{\mathrm{b}}$ & $3.89^{\mathrm{a}}$ & $4.80^{\mathrm{a}}$ & 0.46 \\
Total feed intake $(\mathrm{kg})$ & 16.48 & 14.87 & 15.24 & 0.02 \\
Feed intake $(\mathrm{kg} /$ day) & 0.42 & 0.50 & 0.49 & 0.01 \\
Feed conversion ratio & $3.42^{\mathrm{b}}$ & $1.26^{\mathrm{a}}$ & $1.10^{\mathrm{a}}$ & 0.04
\end{tabular}

${ }^{\mathrm{ab}}$ means in the same row with different superscripts differ significantly $(\mathrm{P}<0.05)$.

Table 4. Haematological indices of grazing Red Sokoto bucks fed dried ripe plantain peel diets

\begin{tabular}{|c|c|c|c|c|c|}
\hline \multirow[b]{2}{*}{ Parameters } & \multirow[b]{2}{*}{ Normal range } & \multicolumn{3}{|c|}{ Treatments } & \multirow[b]{2}{*}{ SEM } \\
\hline & & $\mathbf{T}_{1}$ & $\mathbf{T}_{2}$ & $T_{3}$ & \\
\hline PCV (\%) & $21-35$ & 23.50 & 23.65 & 25.00 & 0.79 \\
\hline $\mathrm{Hb}(\mathrm{g} / \mathrm{dl})$ & $7-15$ & 9.85 & 9.90 & 10.30 & 0.26 \\
\hline $\mathrm{RBC}\left(\mathrm{x} 10^{6} / \mathrm{ul}\right)$ & $3.5-13.5$ & 5.70 & 5.66 & 5.96 & 0.15 \\
\hline WBC $\left(\times 10^{3} / \mathrm{ul}\right)$ & $4-12$ & 9.60 & 11.50 & 12.00 & 0.72 \\
\hline Platelets (x103/ul) & $150-230$ & $202.30^{\mathrm{b}}$ & $202.40^{\mathrm{b}}$ & $212.91^{\mathrm{a}}$ & 10.02 \\
\hline Neutrophil (\%) & $28-42$ & 39.00 & 40.66 & 46.67 & 2.76 \\
\hline Lymphocytes (\%) & $40-60$ & 52.50 & 48.33 & 42.67 & 2.61 \\
\hline Eosinophils (\%) & $0-10$ & 2.50 & 3.33 & 2.67 & 0.35 \\
\hline Monocytes (\%) & $2-10$ & 6.00 & 7.67 & 8.00 & 0.68 \\
\hline
\end{tabular}

${ }^{a b c}$ Means within rows with different superscripts differ $(\mathrm{P}<0.05)$ significantly.

$\mathrm{Hb}=$ haemoglobin, $\mathrm{PCV}=$ Packed cellvolume, $\mathrm{WBC}=$ White blood cell, $\mathrm{RBC}=$ Red blood cell, $\mathrm{SEM}=\mathrm{Standard}$ error of mean.

The serum biochemical indices of Red Sokoto bucks fed dried ripe plantain peel diet is shown in Table 5. There were significant differences $(\mathrm{P}<0.05)$ in the ALP, total protein, urea and creatinine values of the bucks. The ALP Alkaline phosphatase was highest in bucks on T3 $(42.00 \mathrm{u} / 1)$. The ALP for $T_{1}$ and $T_{2}$ fell within the normal range of $12-34 \mathrm{u} / \mathrm{l}$ reported by RAR (2009). ALP is a hydrolase enzyme responsible for dephosphorylation. A range of $52.3-60.00 \mathrm{~g} / 1$ total protein reported in this study compared favourably with a normal range of $30-65 \mathrm{~g} / 1$ reported by RAR (2009). Total protein is the totality of all serum proteins in the form of albumin and globulin whose function is osmotic regulation, immunity, coagulation and transportation of substances (Ikhimioya and Imasuen 2007). A range of 8.00 $10.00 \mathrm{~m} / \mathrm{mol}$ urea reported in this study fell within the normal range of 1.0 - 


\section{Ukanwoko, Douglas and Igwe}

$10.50 \mathrm{~m} / \mathrm{mol}$ urea (RAR 2009). Urea levels higher than normal signify excessive tissue protein breakdown (Opara et al., 2010). Creatinine value is highest in $\mathrm{T}_{2}$ $(141.00 \mathrm{~m} / \mathrm{mol})$ and lowest in $T_{1}$ $(72.50 \mathrm{~m} / \mathrm{mol})$. The creatinine values in this study fell within the normal range (60 -
$140 \mathrm{~m} / \mathrm{mol}$ ) reported by RAR (2009). At the levels higher than normal, creatinine is associated with kidney diseases (Kaneko, 2009). The findings of this study is in agreement with reports of Okoruwa et al. (2014) who observed that inclusion of plantain peels with elephant grass affected the Creatinine and Urea values.

Table 5: Serum biochemical indices of grazing Red Sokoto bucks fed dried ripe plantain diets

\begin{tabular}{llclcl}
\hline Parameters & Normal range & \multicolumn{3}{c}{ Treatments } & \multicolumn{2}{c}{ SEM } \\
& & $\mathbf{T}_{\mathbf{1}}$ & $\mathbf{T}_{\mathbf{2}}$ & $\mathbf{T}_{\mathbf{3}}$ & 1.70 \\
\hline AST $(\mathrm{u} / \mathrm{l})$ & $58-90$ & 12.50 & 15.67 & 14.33 & 0.62 \\
ALT $(\mathrm{u} / \mathrm{l})$ & $10-30$ & 9.15 & 9.30 & 9.10 & 4.55 \\
ALP $(\mathrm{u} / \mathrm{l})$ & $12-34$ & $29.00^{\mathrm{c}}$ & $30.30^{\mathrm{b}}$ & $42.00^{\mathrm{a}}$ & 4.35 \\
TP $(\mathrm{g} / \mathrm{l})$ & $30-65$ & $60.00^{\mathrm{a}}$ & $52.30^{\mathrm{b}}$ & $53.30^{\mathrm{b}}$ & 1.49 \\
Albumin $(\mathrm{g} / \mathrm{l})$ & $20-42$ & 37.00 & 32.30 & 35.00 & 1.09 \\
K $(\mathrm{m} / \mathrm{mol})$ & $3.0-6.0$ & 2.85 & 2.93 & 2.97 & 0.17 \\
Chloride $(\mathrm{m} / \mathrm{mol})$ & $50-95$ & 76.50 & 66.00 & 86.00 & 4.31 \\
Urea $(\mathrm{m} / \mathrm{mol})$ & $1-10.5$ & $8.00^{\mathrm{c}}$ & $10.00^{\mathrm{a}}$ & $9.70^{\mathrm{b}}$ & 0.70 \\
Creatinine $(\mathrm{m} / \mathrm{mol})$ & $60-140$ & $72.50^{\mathrm{c}}$ & $141.00^{\mathrm{a}}$ & $112.30^{\mathrm{b}}$ & 12.39 \\
\hline
\end{tabular}

${ }^{\mathrm{abc}}$ means within rows with different $\quad$ superscript significantly different $(\mathrm{P}<0.05), \mathrm{AST}=\quad$ Aspartate
aminotransferase, $\mathrm{ALT}=$ Alanine Aminotransferase, $\mathrm{ALP}=$ Alkaline Phosphatase, $\mathrm{TP}=$ Total Protein, $\mathrm{K}=$

Potassium, SEM= Standard Mean Error, source (normal range): RAR 2009

\section{Conclusion}

The study showed that the inclusion of dried ripe plantain peel in the diet of Red Sokoto bucks enhanced their body weight gain, hence $\mathrm{T}_{3}(10 \%$ dried ripe plantain peel diet $)$ is recommended for goat production. The utilization of dried ripe plantain peel diets by Red Sokoto bucks did not have any adverse effect on the haematological and serum biochemical indices of Red Sokoto bucks and are therefore recommended for use in goat production.

\section{References}

Abdu, S. B., Hassan, M. R., Jokthan, G. E., Adamu, H. Y., Yashim, S. M. and Yusuf, K. 2012. Effect of varied inclusion levels of Gmelina (Gmelina arborea) leaf meal on intake, digestibility and nitrogen in Red Sokoto bucks fed on sorghum glum based complete diets. Advances in Agriculture, Sciences and Engineering Research. 2(2):79-84.

Adamu, A. S., Ono, I. O. and Oyetunde, J. G. 2017. Evaluation of nutritional values in ripe, unripe, boiled and roasted plantain (Musa paradisiaca) pulp and peel. European Journal of Basic and Applied Sciences. 4(1): 9-12.

Akinsanmi A. O., Oboh G., Akinyemi J., Ayodele, A. and Adefegha A. S. 2015. Assessment of the Nutritional, Anti nutritional and Antioxidant capacity of Unripe, ripe, and over ripe Plantain (Musa paradisiaca) Peels. International Journal of Advanced Research. 3(2): 63-72.

Amata, I. A. 2014. The use of nonconventional feed resources (NCFR) for livestock feeding in the tropics. Journal of Global Biosciences.3(2), 604-613. 
Growth performance, haematological and biochemical indices of grazed Red Sokoto bucks

Ben Salem, H., Nefzaoui, A. and Ben Salem, L. 2004. Spineless cactus (Opuntia ficus indica f. inermis) and oldman saltbush (Atriplex nummularia L.) as alternative supplements for growing Barbarine lambs given straw based diets. In: Small Ruminant Research, 51: 65-73.

Duncan, D. B. 1955. Multiple Range and Multiple F-Tests. Biometrics 11: 1 -42 .

FAO 2005. Production yearbook for 2005 , FAOSTAT Data, Food and Agriculture organisation of the United Nations.

Fanimo, A. O. and Odu, S. 1996. Effect of ripe plantain peel (Musa cv) on growth and carcass performance of growing rabbits. Pertanika Journal of Tropical Agricultural Science. 19(1): 89-93.

Gizzi, G. and Givens, D. I. 2004. Variability in feed composition and its impact on animal production. In: Assessing quality and safety of Animal feeds. FAO Animal Production and $\mathrm{H}$ e a $1 \mathrm{th}$ paper 160. FAO, United Nations. Pp 36-52.

Ijeomah, H. M., Chima, U. D. and Okagbare, O. H. 2013 . Ecological Survey of Avifaunal Resources in University of Port Harcourt, Nigeria. Ethiopian Journal of Environmental studies and Management. 6(6): $648-660$.

Ikhimioya, I. and Imasuen J.A. 2007 Blood Profile of West African Dwarf goats fed Panicum maximum supplemented with Afzelia Africana and Newbouldia Leaves Pakistan Journal of Nutrition 5:79-84.

Joshi, P. K., Bose, M. and Harish, D. 2002. Changes in certain haematological parameters in a Siluroid catfish Clarias batrachus (Linn.) exposed to cadmium chloride. Pollution Research. 21(2): $129-131$.

Kalio, G. A., Ayuk, A. A. and Agwunobi, L. N. 2013. Performance and Economics of production of West African Dwarf (WAD) bucks fed crop by - products as sole feed in Cross Rivers State, Nigeria. World Journal of Agricultural Sciences. 1(3): $081-087$.

Kaneko, J. J. 2009. Clinical biochemistry of domestic animals. $6^{\text {th }}$ Ed. New York Academic press.

National Agricultural Sample Survey. 2011. Collaborative Survey on National Agriculture Sample Survey (NASS), 2010/2011. $\mathrm{N}$ a t i o n a 1 B u r e a of Statistics/Federal Ministry of Agriculture and Rural Development. Available at: http://nigeria.countrystat.org/docu ments/detail/en/c/454 834/. Pp: 143.

Ogunsami, A. O., Akpavieso, P. A. and Anosa, V. O. 2002. Serum biochemical changes in WAD sheep experimentally infested with Trypasoma brucei. Tropical Veterinarian 47(2): 195.

Okafor, E. C., Lakpini, C. A. M. and Fayomi, A. 2012. Dried Gmelina (Gmelina arborea Roxb) leaves as replacement forage to groundnut haulms in the diets of fattening Red $\mathrm{S}$ o k o t o b u c k s. International Journal of Agriculture and Biosciences. 1: $5-$ 10.

Okoruwa, M. I. and Edokpayi, I. M. 2014. Evaluation of energy utilization and haematological indices of West African Dwarf goats fed varying levels of yam 


\section{Ukanwoko, Douglas and Igwe}

peels and cowpea chusk. Scholars Journal of Agriculture and Veterinary Sciences. 1(4A):255 -259 .

Oladele, E. and Khokhar S. 2011. Effect of domestic cooking on the polyphenolic content and antioxidant capacity of Plantain (Musa paradisiaca). World Journal of Dairy and Food Sciences, 6(2): 189-194.

Onyeonagu, C. C. and Njoku, O. L. 2010. Crop residues and agro-industrial by-products used in traditional sheep and goats production in rural communities of Makurdi LGA. Journal of Tropical Agriculture, Food, Environment and Extension. 9(3): 161 - 169.

Opara, M. N., Udevi, N. and Okoli, I. C. 2010. Haematological parameters and blood chemistry of apparently healthy West African Dwarf (WAD) goats in Owerri, South Eastern Nigeria. New York Science Journal. 3(8): 68-72.

Raji, A. Y., Butswat, I. S. R., Njidda, A. and Jolani, I. 2016. Blood components of Red Sokoto goats fed Moringa oleifera (1) leaf meal supplemented diets. Nigerian Journal of Animal production. 43(1):
Research Animal Resource [RAR]. 2009. Reference values for laboratory animals: Normal haematological values. RAR Websites, RAR, University of Minnesota. $\mathrm{R}$ e $\mathrm{t} \mathrm{r}$ i e $\mathrm{ved}$ f $\mathrm{r}$ o $\mathrm{m}$ http://www.ahc.umn.edu/rar/refval ues.html

Rashid, M. 2008. Goats and their Nutrition. www.manitobagoats.ca

Sodeinde, F. G., Asaolu, V., Oladipo, M.A., Akinlade, J. A., Ige, A. O., Amao, S. R. and Alalade, J. A. 2007. Mineral and anti-nutritional contents of some forage legumes consumed by small ruminants in the derived savanna of Nigeria. Research Journal of Agronomy, 1(1):30-32.

Steel, R. G. D. and Torrie, J. H. 1980. Principles and Procedure of Statistics. $2^{\text {nd }}$ Ed. McGraw Hill Book Co. Inc. New York.

Ukanwoko, A. I., Adamu, F. O. and Okah, U. 2019. In vitro digestibility and nutrient profile of dried and ensiled ripe and unripe plantain peels. Nigerian Journal of Animal Science. 21(2): 155-164.

Received: $19^{\text {th }}$ September, 2019 Accepted: $27^{\text {th }}$ January, 2020 